\title{
Ozone Therapy Immunomodulatory Effect in the Selective Immunoglobulin A Deficiency
}

\author{
Jacqueline Diaz-Luis ${ }^{1}$, Silvia Menendez-Cepero² and Consuelo Macias- \\ Abraham $^{3}$ \\ 1"Roberto Rodriguez Fernandez" University Hospital. Moron, Cuba. 2Prodanza Center. Ozone Clinic. \\ Havana, Cuba. ${ }^{3 H e m a t o l o g y}$ and Immunology Institute. Havana City, Cuba.
}

doi: 10.7203/jo3t.1.1.2015.12161

Received: October, 2015

Published: December 2015

\section{ABSTRACT}

Purpose: The aim of this work is to study the ozone therapy effect in the selective immunoglobulin A deficiency. Patients and methods: Taking into account that ozone is able to stimulate several biological systems, to modulate cytokines levels and to enhance immunoglobulin production, a phase II, controlled and randomized, clinical trial was performed. Forty patients were divided at random into 2 groups of 20 patients each: Ozone - received 42 sessions by rectal insufflations during three months, using scaling doses. Control - received subcutaneous Hebertrans during three months. Patients were evaluated at the beginning and one and six months later. Results: The IgA improved, with significant difference $(\mathrm{p}=0.04)$ between both groups. The blood levels of IgG were increased significantly $(\mathrm{p}=0.03)$ in the group treated with ozone compared to the control group. Leukocyte activity improved significantly $(\mathrm{p}=0.04)$ one month later, achieving $97 \%$ of normal values. The clinical evolution was satisfactory in 87 and $80 \%$ of the children that received ozone and Hebertrans, respectively without side effects reported.

Keywords: Ozone Therapy, Immunoglobulin A Deficiency, Immunological Parameters, Cytokines, Subcutaneous Hebertrans.

\section{INTRODUCTION}

Primary immune deficiency disorders represent a highly heterogeneous group of disorders with an increased predisposition to infections and other immune complications. Approximately $50-60 \%$ of all identified primary immunodeficiencies are caused by defects in antibody production (1). Selective immunoglobulin A (IgA) deficiency is a predominantly antibody deficiencies for the isotype o light chain deficiency with generally normal numbers of B cells. It is defined as an undetectable or absent serum IgA level, being total IgA deficiency (IgAD) at a value $<0.07 \mathrm{~g} / 1$ or partial $\operatorname{IgAD}$ when the value is less than two standard deviations below the age-adjusted normal in a patient older than 4 years of age. The genetic defect is unknown, the inheritance is variable, and Individuals with this deficiency lack immunoglobulin A, a type of antibody that protects against infections of the mucous membranes as the

\section{Authors Information}

\section{E-mail address: jdiaz@hgm.cav.sld.cu}

mouth, airways, and digestive tract (2). This is why IgA is known as the secretary antibody. It is the most common of the primary antibody deficiencies (3].

The IgAD causes are unknown; it may vary from individual to individual, the $\mathrm{B}$ lymphocytes are normal, but there is a failure of terminal differentiation in IgA-positive B cells. B-lineage cell development occurs in the fetal liver and then, it is transferred to the bone marrow (when it becomes the major hematopoietic organ). Pre- B cells become immature immunoglobulin $\mathrm{M}$ positive $\mathrm{B}$ cells and then migrate from the bone marrow to lymph node germinal centers. After leaving the bone marrow, the B cells mature and express immunoglobulin $\mathrm{D}(\mathrm{IgD})$ receptor, respond antigens and with the help of $\mathrm{T}$ cells (CD4+), undergo proliferation and class switching and differentiation into plasma cells. These processes are regulated by cell interaction molecules, cytokines and their cell surface receptors (4).

The defect in these patients is a block in the differentiation of B cells to IgA antibody-secreting plasma cells. The $\alpha$ heavy chain genes and the expression of membrane- associated IgA are 
normal. No gross abnormalities in the numbers, phenotypes or functional responses of $\mathrm{T}$ cell have been noted in this patient. Based on animal studies, the failure of $\mathrm{B}$ cell to terminally differentiate into IgA-secreting plasma cells is due to the lack of signals produced by co-stimulatory molecules or cytokines such as cytokines like IL-4, Il-5, IL-6, IL-7 and transforming growth factor- $\beta$ (TGF- $\beta 1$ ) (5).

The IgAD is a heterogeneous and polysymptomatic disease, the associated features usually asymptomatic, may have recurrent infections that cause bronchiectasis, ears infections, sinusitis, bronchitis, pneumonia and chronic lung damage. Some patients may have intestinal parasite infections, chronic diarrheas and malnutrition. The infections are not completely eliminated with treatment and the patients must have to remain with antibiotics for longer time than usual (4); with poor antibody responses to carbohydrate antigens and allergies or autoimmune disease. The allergies more common in individuals with $\operatorname{IgAD}$ is bronchial asthma, being more severe and less responsive to therapy; other types of allergy associated are food allergies, allergic rhinitis or eczema and gluten sensitive enteropaty (6). Another problem common is the occurrence of autoimmune disease. Some of the more frequent autoimmune diseases associated are: rheumatoid arthritis, systemic lupus erythematosus and other kinds of autoimmune disease that can affect the endocrine system and/or the gastrointestinal system (7).

There is not specific treatment for the underlying disorder. It is impossible to replace the $\operatorname{IgA}$ deficiency in patients with commercial medicaments (5). The treatment consists in the identification of co morbid conditions and preventive measures to reduce the risk of infection; individual infections should be treated with appropriate antibiotic. People without any $\operatorname{IgA}$ can develop anti-IgA antibodies causing severe reactions after receiving blood products that contain $\operatorname{IgA}(8,9)$. The Dialyzable Leukocyte Extract (DLE) is a complex extract derived from immune leukocytes containing low-molecular weight entities capable of transferring cellmediated immunity (10). That is, DLE obtained from individuals with strong reactivity to a specific antigen will develop a delayed hypersensitivity reaction in recipients that have never been exposed to this antigen. Clinical trials using DLE have been performed in several diseases; it has been applied with effectiveness in the IgAD (11).
Ozone therapy is a natural therapeutic procedure, becoming increasingly important in medicine due to its effectiveness in several illnesses, improving immune functions without side effects (12). Furthermore, ozone therapy is currently the only procedure able to modify the biological answer, particularly the stimulation of immunological mechanisms, such as to enhanced immunoglobulin production, to activate phagocytosis in immune cells, to allow a mild activation of neutrophils and the induction of some cytokines, to enhance the transport and release of oxygen to tissues and to stimulate the antioxidant defense system achieving a redox balance (13). The leucocytes migrate all over the body and can slowly improve the response of the adaptive immune system (14). It is considerate an ideal immunomodulator, because is atoxic, non-tolerogenic and non-antigenic for the immune system $(15,16)$.

Based on preclinical and clinical investigations (17, $18,19,20,21,22)$, ozone rectal insufflation is increasingly being used as a systemic therapeutic form, and is already being viewed as an alternative to major autohemotherapy. Ozone rectal administration produces, in animal experiments, an increase in partial oxygen pressure in the intestinal wall and in the mesenteries blood vessels, in the portal vein and in liver parenchyma being a proof of intestinal wall diffusion $(17,18)$.

Rectal ozone application is simple, low-cost and practically free of adverse reactions when doses are well used. In addition, rectal ozone insufflation is being increasingly used in pediatrics because it is a save modality and stimulates several biological systems without deleterious effects (13). Taking into account these ozone effects, the aim of this study is to evaluate the immunomodulatory efficacy of ozone therapy in children with IgA deficiency.

\section{PATIENTS AND METHODS}

A phase II clinical trial, controlled, randomized and evaluated by a third masked reader was performed. This study was approved by the Scientific and Ethical Committee of the hospital. Forty patients that fulfill the inclusion criteria (older than 4 years of age, relapses $\geq 8$ in one year, respiratory and digestive infections with IgA deficiency, signed informed consent and without immunostimulant treatment, nor blood transfusions, during the 6 previous months) were divided at random into 2 groups of 20 patients each: ozone - patients received 42 sessions of ozone by rectal insufflations during three months. The initial ozone 
concentration was $15 \mu \mathrm{g} / \mathrm{mL}, 5 \mu \mathrm{g} / \mathrm{mL}$ were increased weekly, until $40 \mu \mathrm{g} / \mathrm{mL}$ with a volume between 40 and $100 \mathrm{~mL}$, depending on the weight of the children (23). Control - patients received subcutaneous Hebertrans during three months, 1 unit per square meter corporal surface weekly (19). Groups were homogenous.

\section{Evaluation criteria}

The evaluation criteria were determined in relation to the clinical state and the microbiological and immunological parameters, such as: number of infections per year, type of infection, number of hospitalizations, WBC count and phagocyte function $(25,26)$, blood levels of $\operatorname{IgG}, \operatorname{IgM}, \operatorname{IgA}$ (26) and autoimmunity test (27). Patients were evaluated at the beginning and one and six months later.

\section{Statistical analysis}

The Statistical Package for Social Sciences (SPSS) version 11.0 was used for all analysis. The comparisons between groups were made using Pearson Chi-square test. Ho was rejected if $\left(\mathrm{X}^{2}\right) \mathrm{c}>$ $\left(\mathrm{X}^{2}\right) \mathrm{t} \mathrm{n}-1 \mathrm{gl}$. Also, Fisher test was applied. It was considered $\mathrm{p}<0.05$ as significant.

\section{RESULTS AND DISCUSSION}

Of the 40 patients enrolled in this study with deficiency of IgA (IgAD) antibody, $75 \%$ were masculine. This result had similar coincidence with a study of 7293 Austrian volunteers showing a greater frequency $\operatorname{IgAD}$ in masculine than in feminine (28).
The IgAD is associated frequently with recurrent infections and others illness that determine its evolution, prognosis and the therapeutic answers (Table 1). The frequency of recurrent infections was more than 10 in one year (in $100 \%$ of patients) and hospitalizations due to sepsis were presented in $56.5 \%$. The recurrent respiratory infections were present in 36 patients $(60 \%)$, with bronchopneumonia 18 patients (45\%), chronic and recurrent infections of the upper respiratory tract 11 patients $(27 \%)$ and a significant increase in rates of recurrent viral infections (62\%). The recurrent gastro intestinal (GI) tract infections more frequently was giardiasis (32\%) and dysbacteriosis $(30 \%)$. Recent studies have demonstrated that $80 \%$ of individuals with $\operatorname{IgAD}$ developed sino/ pulmonary infections or GI infections, various GI tract infections with viruses, bacteria and parasites manifest as diarrhea $(5,6,9)$.

Cellular and molecular analyses suggest that $\operatorname{IgA}$ antibodies are transported in secretions to mucosal surfaces and play a major role in protecting these surfaces from infection. This is why there is an increase of the mucous infections in the $\operatorname{IgAD}(3)$.

The bronchial asthma was present in 17 patients $(42.5 \%)$.There are evidences that $\operatorname{IgAD}$ in the mucous membranes is associated with an increased prevalence of atopic, suggesting a possible role of IgA in asthma pathogenesis. A protective role of IgA has been demonstrated in murine models of asthma (29). It is possible that in the absence of IgA, mucosal antigen exposure is increased, which may lead to increased IgE against inhalants or food

Table 1: Associated illness in patients with IgA deficiency

\begin{tabular}{lcc}
\hline \multicolumn{1}{c}{ Illness } & № & $\%$ \\
\hline Recurrent respiratory infections (bronchopneumonia) & 18 & 45 \\
\hline $\begin{array}{l}\text { Chronic and recurrent infections of the upper respiratory } \\
\text { tract (acute middle ear otitis, acute tonsillitis) }\end{array}$ & 11 & 27 \\
\hline Viral infections & 24 & 62 \\
\hline Bronchial asthma & 17 & 42,5 \\
\hline Autoimmunity disease & 2 & 5 \\
\hline Recurrent gastro intestinal tract infections (giardiasis) & 13 & 32 \\
\hline Dysbacteriosis & 12 & 30 \\
\hline
\end{tabular}


antigens (30). In this study autoimmune diseases was present in 2 patients (5\%) with IgAD; the sera of individuals with $\operatorname{IgAD}$ may contain various auto antibodies that cause no disease or cause disease as: rheumatoid arthritis and systemic lupus erythematosus (7). There is evidence that patients with IgAD may develop auto antibodies anti-IgA and can develop severe reactions when they are transfused with blood components that contain IgA $(8,9)$.

The treatment of IgAD consists in the identification of the problems associated and to use the appropriate treatment, because it is not currently possible to replace $\operatorname{IgA}$ in $\operatorname{IgAD}$ patient $(5,31)$. Hebertrans has demonstrated a good effectiveness in this illness, but it is expensive $(11,32)$. Ozone therapy is a therapeutic procedure that activates immune system $(33,34$, and 16). It is well documented that ozone can activate monocyte and lymphocytes and can induce the production of an array of cytokines, such as interleukin-2, interferon, tumor-necrosis factor and colony stimulating factors $(31,35)$. Its ability to elicit endogenous production of cytokines and its lack of toxicity make ozone an indispensable therapeutic modality, since today's most devastating diseases are characterized by immune depression $(33,36)$.

In this study the blood levels of IgA were increased progressively in 20 children treated with ozone, with significant difference $(\mathrm{p}=0.04)$ between both groups (Table 2). This is an important result because the $\operatorname{IgA}$ is the parameter more precise to demonstrate the effectiveness of ozone therapy in
IgAD (figure 1). (Table 3); however, the $\operatorname{IgM}$ showed not significant increase. As a response to this activation due to ozone therapy, there are cytokines setting off a cascade of positive changes throughout the immune system and the immunoglobulin production is a process that needs the intercellular signaling mediated by cytokines (4, 37). The cytokines secreted by helper $T$ cells are the second signals for B lymphocyte activation. The cytokines mediate many of the effectors functions of the cells that produce them and can activate locally other immune cells leading to immune activation. This is the principal mechanisms by which various immune and inflammatory cell populations communicate with one another. The cytokine themselves are not antigen-specific and do not bind to antigens (4). The ozone as an immune modulator produces the induction and release of cytokines. As reaction products of ozonolysis on phospholipids of the cell membrane, hydroperoxides reach the intracellular area along this path to influence cellular metabolism. In the case of the immunocompetent cells they possibly occurred via a non-specific activation of nuclear factor $\mathrm{k} \beta(38)$.

Cytokines have two principal functions in antibody responses: they determine the types of antibodies produced by selectively promoting switching to different heavy chain isotype and they provide amplification mechanisms by augmenting B cell proliferation and differentiation $(37,39)$. The in vitro experiments have showed that IL-4, IL-2 and IL-5 are the most potent inducer of IgM antibody

Table 2: IgA values in patients with IgA deficiency treated with Ozone therapy or Hebertrans.

\begin{tabular}{|c|c|c|c|c|c|c|c|c|c|c|c|c|}
\hline \multirow{3}{*}{$\lg A$} & \multicolumn{6}{|c|}{ Ozone } & \multicolumn{6}{|c|}{ Hebertrans } \\
\hline & \multicolumn{2}{|c|}{ Initial } & \multicolumn{2}{|c|}{1 month } & \multicolumn{2}{|c|}{6 months } & \multicolumn{2}{|c|}{ Initial } & \multicolumn{2}{|c|}{1 month } & \multicolumn{2}{|c|}{6 months } \\
\hline & № & $\%$ & № & $\%$ & № & $\%$ & № & $\%$ & № & $\%$ & № & $\%$ \\
\hline $\begin{array}{r}\text { Normal } \\
0.5-2.3 \mathrm{~g} / \mathrm{L}\end{array}$ & & & 8 & 40 & 10 & 50 & & & 4 & 20 & 8 & 43 \\
\hline $\begin{array}{l}\text { Decreased } \\
<0.5 \mathrm{~g} / \mathrm{L}\end{array}$ & 20 & 100 & 12 & 60 & 10 & 50 & 20 & 100 & 16 & 80 & 12 & 57 \\
\hline Total & 20 & 100 & 20 & 100 & 20 & 100 & 20 & 100 & 20 & 100 & 20 & 100 \\
\hline$\mu e(g / L)$ & \multicolumn{2}{|c|}{0.01} & \multicolumn{2}{|c|}{0.20} & \multicolumn{2}{|c|}{$0.50^{a}$} & \multicolumn{2}{|c|}{0.01} & \multicolumn{2}{|c|}{0.25} & \multicolumn{2}{|c|}{$0.35^{b}$} \\
\hline$X^{2}$ & & $\begin{array}{l}0 * \\
00^{*}\end{array}$ & \multicolumn{2}{|c|}{$\begin{array}{c}1.60^{\star *} \\
p=0.20^{* *}\end{array}$} & \multicolumn{2}{|c|}{$\begin{array}{c}3.95^{\star * *} \\
p=0.04^{* * *}\end{array}$} & \multicolumn{2}{|c|}{$\begin{array}{c}0.00^{*} \\
p=1.00^{*}\end{array}$} & \multicolumn{2}{|c|}{$\begin{array}{c}1.60^{* *} \\
p=0.20^{* *}\end{array}$} & \multicolumn{2}{|c|}{$\begin{array}{c}3.95^{* * *} \\
p=0.04^{* * *}\end{array}$} \\
\hline
\end{tabular}

The letters represent Statistical significance between $a$ and $b$ of at least $P<005$ among the medium $(\mu \mathrm{e})$ of the IgA determinations for both treatments. $X^{2}$ represent the analyses among the groups by the Pearson Chi- square test: initial $\left({ }^{\star}\right)$; after 1 month $\left(^{\star \star}\right)$ and 6 months $\left(^{(\star \star}\right)$. 
Figure 1: Number of patients with normal or decreased IgA levels at 1 and 6 months of evolution in both groups of treatment.

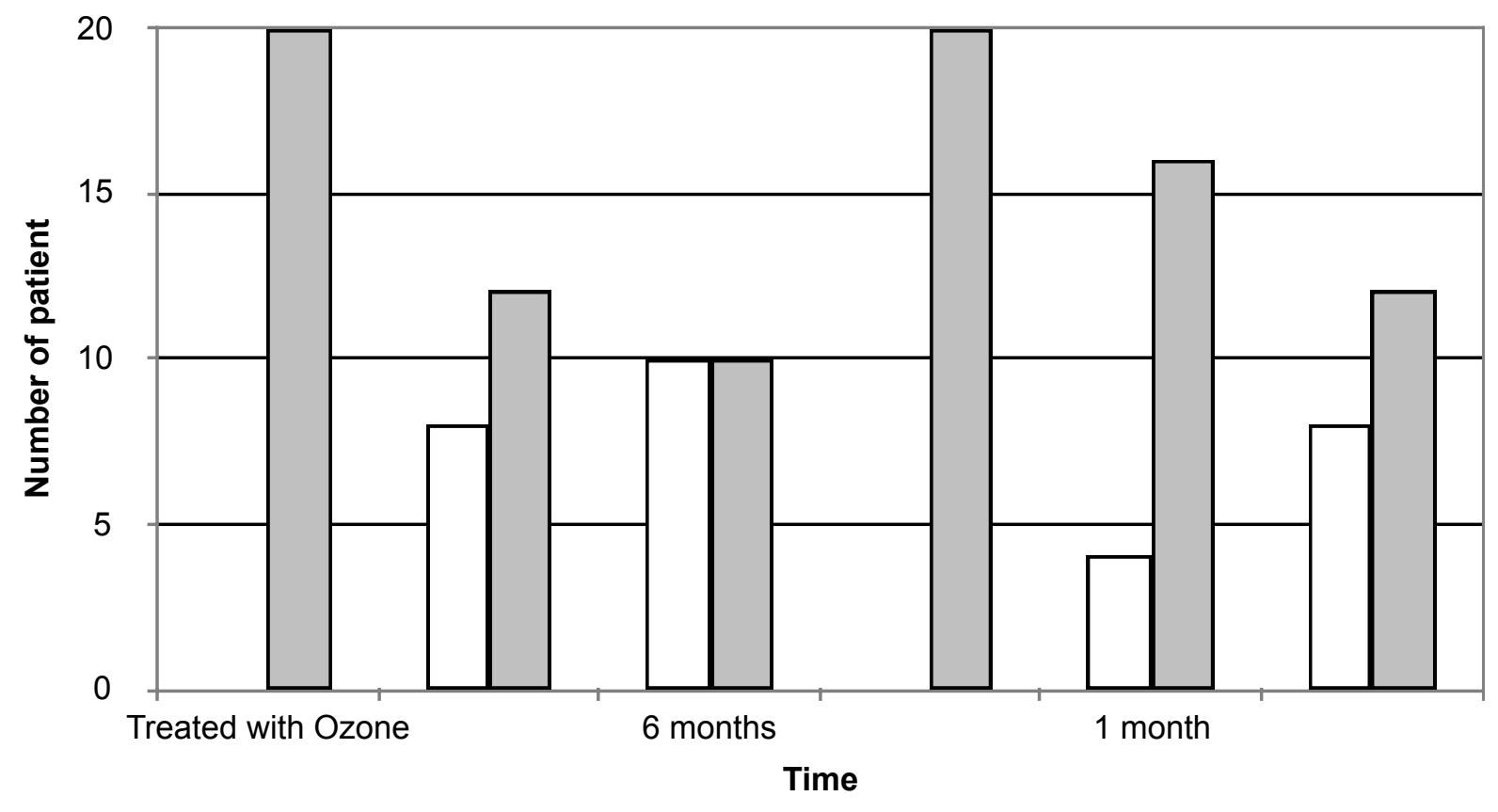

normal $\square$ Decreased

Table 3: IgG values in patients with IgA deficiency treated with Ozone therapy or Hebertrans

\begin{tabular}{|c|c|c|c|c|c|c|c|c|c|c|c|c|}
\hline \multirow{3}{*}{$\lg G$} & \multicolumn{6}{|c|}{ Ozone } & \multicolumn{6}{|c|}{ Hebertrans } \\
\hline & \multicolumn{2}{|c|}{ Initial } & \multicolumn{2}{|c|}{1 month } & \multicolumn{2}{|c|}{6 months } & \multicolumn{2}{|c|}{ Initial } & \multicolumn{2}{|c|}{1 month } & \multicolumn{2}{|c|}{6 months } \\
\hline & № & $\%$ & № & $\%$ & № & $\%$ & № & $\%$ & № & $\%$ & № & $\%$ \\
\hline $\begin{array}{l}\text { Normal } \\
7-14 \mathrm{~g} / \mathrm{L}\end{array}$ & 17 & 85 & 17 & 88 & 19 & 95 & 14 & 70 & 15 & 75 & 15 & 75 \\
\hline $\begin{array}{c}\text { Decreased } \\
<7 \mathrm{~g} / \mathrm{L}\end{array}$ & 3 & 15 & 3 & 12 & 1 & 5 & 6 & 30 & 5 & 25 & 5 & 25 \\
\hline Total & 20 & 100 & 20 & 100 & 20 & 100 & 20 & 100 & 20 & 100 & 20 & 100 \\
\hline$\mu e(g / L)$ & \multicolumn{2}{|c|}{8.36} & \multicolumn{2}{|c|}{$9.09 a$} & \multicolumn{2}{|c|}{$10.64^{a}$} & \multicolumn{2}{|c|}{7.62} & \multicolumn{2}{|c|}{7.92 b } & \multicolumn{2}{|c|}{$8.22^{b}$} \\
\hline$X^{2}$ & \multicolumn{2}{|c|}{$0.40^{*}$} & \multicolumn{2}{|c|}{$\begin{array}{c}8.12^{* *} \\
p=0.04^{* *}\end{array}$} & \multicolumn{2}{|c|}{$\begin{array}{c}8.64^{* * *} \\
p=0.03^{* * *}\end{array}$} & \multicolumn{2}{|c|}{$\begin{array}{c}0.40^{*} \\
p=0.52^{*}\end{array}$} & \multicolumn{2}{|c|}{$\begin{array}{c}8.12^{* *} \\
p=0.04^{* *}\end{array}$} & \multicolumn{2}{|c|}{$\begin{array}{c}8.64^{* * *} \\
p=0.03^{* * *}\end{array}$} \\
\hline
\end{tabular}

Different letters represent Statistical significance between a and b of at least $\mathrm{P}<005$ among the medium $(\mu \mathrm{e})$ of the IgG determination at 1 and 6 months for both different treatments. $X^{2}$ represent the analyses among the groups by the Pearson Chi- square: initial $\left(^{*}\right)$; after 1 month $\left({ }^{* \star}\right)$ and 6 month $\left({ }^{* *}\right)$.

secretion by $\mathrm{B}$ cells $(3,4)$. The isotype switching is a process regulated by cytokines. IL-2, IL-4, IL- 6 and IFN- $\delta$ induce specific isotype switching to IgG and transforming growth factor- $\beta$ (TGF- $\beta$ ) and IL-5 to stimulate IgA productions in mucosal lymphoid tissues $(39,3)$. It is important to know the ability to induce cytokine release in a practically physiological manner i.e. without the severe, undesirable adverse reactions such as medical interferon.

Other immune system defect was presented in children with IgAD. The phagocyte function was depressed in 10 to $25 \%$ of patients. It is possible that the recurrent infection present in the children 
with IgAD, supposes a not well oxygenated environment in the cells and therefore, a condition that depress the defensive activity of leukocytes is present, failing in the elimination of germs (40). With the ozone treatment leukocyte activity improved significantly one month later, achieving $97 \%$ of normal values, with significant differences $(p=0.04)$ between both groups (Table 4). It is important to point out that the effectors immunological mechanisms against the microorganism are oxygen dependent (41).

Several studies have demonstrated the molecular basis of ozone activity in leucocytes $(15,16,34)$. After ozone administration there is an increase of the acute-phase proteins, cytokines and GM-CSF, producing leukocytosis. This condition increases the defensive activity of leukocytes and also modulates its answer. The general oxygenating effect has favorable consequences on the body; the energy is reactivated with ozone therapy (13).
The cell fatigue, often sequel of viral or bacterial infectious processes present in these patients, also is improved by the stimulant effect of the ozone. The cell needs oxygen to obtain the energy to live. When the cells absorb the oxygen, they send it to the mitochondria and the metabolism is completed (that is not more than a series of chemical reactions of combustion) obtaining the energy that makes the cell stays alive. In the mitochondria are synthesized the vitamins, the proteins and the minerals. The more oxygen is absorbed by the cell; there will be a better combustion. The oxygenation of the cells affects favorably the immunologic system that strengthening the white globules (42).

Table 5 shows that the clinical evolution was satisfactory in 87 and $80 \%$ of the children that received ozone and Hebertrans, respectively, without significant differences between the groups. In general, it was observed better quality of life, increase in immunological parameters and smaller

Table 4: Phagocyte function in patients with IgA deficiency treated with Ozone therapy or Hebertrans.

\begin{tabular}{|c|c|c|c|c|c|c|c|c|}
\hline \multirow[t]{3}{*}{ Phagocyte function } & \multicolumn{4}{|c|}{ Ozone } & \multicolumn{4}{|c|}{ Hebertrans } \\
\hline & \multicolumn{2}{|c|}{ Initial } & \multicolumn{2}{|c|}{1 month } & \multicolumn{2}{|c|}{ Initial } & \multicolumn{2}{|c|}{1 month } \\
\hline & № & $\%$ & № & $\%$ & № & $\%$ & № & $\%$ \\
\hline $\begin{array}{l}\text { Normal } \\
28-54 \%\end{array}$ & 14 & 70 & 19 & 97 & 15 & 77 & 17 & 87 \\
\hline $\begin{array}{c}\text { Decreased } \\
\quad<28 \%\end{array}$ & 6 & 30 & 1 & 3 & 5 & 23 & 3 & 13 \\
\hline Total & 20 & 100 & 20 & 100 & 20 & 100 & 20 & 100 \\
\hline$\mu e(\%)$ & \multicolumn{2}{|c|}{31.5} & \multicolumn{2}{|c|}{$37^{a}$} & \multicolumn{2}{|c|}{32.8} & \multicolumn{2}{|c|}{$34^{b}$} \\
\hline$x^{2}$ & \multicolumn{2}{|c|}{$0.10^{*}$} & & & \multicolumn{2}{|c|}{$0.10^{*}$} & \multicolumn{2}{|c|}{$3.98^{* *}$} \\
\hline
\end{tabular}

The different letters represent significant differences $(p<0.05)$ among the medium $(\mu \mathrm{e})$ of the phagocyte function determinations between both groups. $X^{2}$ represent the analyses among the groups by the Pearson Chi- square test: initial $\left(^{*}\right)$ and after the 1 month $\left(^{* *}\right)$

Table 5: Clinical evolution of the patients with IgA deficiency after the treatment with ozone or Hebertrans

\begin{tabular}{ccccc}
\hline Clinical evolution & \multicolumn{2}{c}{ Ozone } & \multicolumn{2}{c}{ Hebertrans } \\
& № & $\%$ & № & $\%$ \\
\hline Satisfactory & 17 & 87 & 16 & 80 \\
Unsatisfactory & 3 & 13 & 4 & 20 \\
\hline Total & 20 & $100 \%$ & 20 & $100 \%$ \\
\hline
\end{tabular}


number of infections and hospitalizations for infection disease.

Aubourg in 1938 (38) was the first to suggest the insufflations of the ozone gas mixture into the colon-rectum and today this approach has been adopted world-wide because it is easy to perform, is inexpensive, risk-free and often beneficial. This modality was selected in this investigation because has no side effects, atoxic and was postulated to have a systemic effect $(17,44)$. How has been suggested by several authors, the rectal insufflations (RI) can exert a local and rapid systemic effect due to absorption of reactive oxygen species (ROS) and lipid oxidations products (LOPS), generated by the reaction of ozone with biomolecules present in the luminal content (17). It has been confirmed in this controlled, randomized clinical trial, the effectiveness of ozone therapy by RI. By this less invasive way of ozone application the children avoid repeated venous punctures.

\section{CONCLUSIONS}

It was demonstrated the immunostimulation effect of ozone therapy on immune humoral responses and phagocyte function in patients with $\operatorname{IgA}$ deficiency. A better quality of life and a smaller number of infectious events and hospitalizations in patients treated with ozone were observed. Ozone therapy offers similar effectiveness to Hebertrans, in IgA antibodies responses, in patients with deficiency of this immunoglobulin. Ozone therapy improves the health and modulates the host's immune system, increasing the oxygen metabolism and cell energy demonstrated in the better clinical shape achieved. No side effects were reported during the treatment.

\section{REFERENCES}

1. Bradley AL, Trivikram D, James WV. Laboratory Diagnosis of Primary Immunodeficiencies. Clinic Rev Allerg Immunol. 2014;46:154-168.

2. Al-Herz W, Bousfiha A, Casanova JL, Chatila $\mathrm{T}$, Conley ME, et al. Primary immunodeficiency diseases: an update on the classification from the International Union of Immunological Societies Expert Committee for Primary Immunodeficiency. Frontiers in immunology. 2014;5(162):1-32.

3. Abbas AK. Regional Immunity: Specialized immune response in epithelial and immune privileged tissues. In: Abbas AK, Lichtman A. Cellular and Molecular Immunology. 7 ed. NY: WB Saunders Co; 2011.

4. Abbas AK. Congenital and acquired immunodeficiencies: Specialized immune response in epithelial and immune privileged tissues. In: Abbas AK, Lichtman A. Cellular and Molecular Immunology. 7 ed. NY: WB Saunders Co; 2011.

5. Yel L. Selective IgA deficiency. J Clin Immunol. 2010;30(1):10-6.

6. Bezrodnik L, Giovanni D, Ginaca A. Evaluación clínica e inmunológica de 90 pacientes con deficiencia selectiva de inmunoglobulina A. Arch Argent Pediatr. 2008;10(5):375-381.
7. Singh K, Chang C, Gershwin ME. IgA deficiency and autoimmunity. Autoimmunity Reviews. 2014;13(2):163-177.

8. Fitzsimons MG, Walton K, Makar R, Dzik W, Kuter D, Vlahakes GJ. Redo aortic valve replacement in a patient with immunoglobulin A deficiency and hemophilia A. Ann Thorax Surg. 2013;96(1):311-313.

9. Domínguez O, Giner MT, Alsina L, Martín MA, Lozano J, Plaza AM. Fenotipos clínicos asociados a la deficiencia selectiva de IgA: revision de 330 casos y propuesta de un protocolo de seguimiento. An Pediatr. 2012;76(5):261-267.

10. Unknown-author. Transfer factor. Available

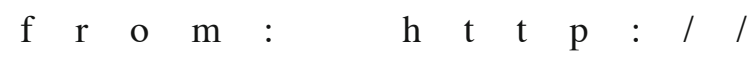
www.factordetransferenciaipn.com.mx/ queesft.htm. [Accessed 1th Mar 2009]

11. Inclan $G$, et al. Immunological and clinical response in patients with IgA deficiency after the treatment with transfer factor. Haematol immunol and Haemotherapy. 1994;10:80-81.

12. Bocci V. Biological and clinical effects of ozone. Has ozone therapy a future in medicine? British Journal of Biomedical Science. 1999;56(4):270-279.

13. Menendez S, Gonzalez R, Ladea OE, Leon OS, Hernandez F, Díaz M. Ozonoterapia: Aspectos 
basicos y aplicaciones clínicas. La Habana, Cuba: Editorial CENIC; 2008.

14. Larini A, Bocci V. Effects of ozone on isolated peripheral blood mononuclear cells. Toxicology in Vitro. 2005;19:55-61.

15. Bocci V. Scientific and medical aspects of ozone Therapy. State of the art. Arch Med Res. 2006;37:425-435.

16. Travagli V, Zanardei I, Silvietti A, Bocci V. A physicochemical investigation on the effect of ozone on blood. Int $\mathrm{J}$ Biol Macromol. 2007;41:504-511.

17. Bocci V, Borrelli E, Corradeshi F, Valacchi G. Systemic effects after colorectal insufflations of oxygen-ozone in rabbits. Int $\mathrm{J}$ Med Biol Environ. 2000;28:109-113.

18. Ajamieh HH, Menendez S, Merino N, Martínez G, Re L, Leon OS. Ischemic and ozone oxidative preconditioning in the protection against hepatic ischemic-reperfusion injury. Ozone Sci Eng. 2003;25(3):241-50.

19. Calunga JL, Trujillo Y, Menendez S, Zamora Z, Alonso Y, Merino N, et al. Ozone oxidative postconditioning in acute renal failure. J Pharm Pharmacol. 2009;61:1-7.

20. Martinez G, Al-Dalain SM, Menendez S, Re L, Giuliani A, Candelario-Jalil E, et al. Therapeutic efficacy of ozone medical treatments in patients with diabetic foot. Eur J Pharmacol. 2005;523:151-161.

21. Hernandez F, Calunga JL, Turrent J, Menendez S, Montenegro A. Ozone therapy effects on blood biomarkers and lung fuction of asthma patients. Arch Med Res. 2005;36(5):549-554.

22. Ajamieh HH, Menendez S, Martinez-Sanchez G, Candelario-Jalil E, Re L, Giuliani A, et al. Effects of ozone oxidative preconditioning on nitric oxide generation and cellular redox balance in a rat model of hepatic ischaemiareperfusion. Liver Int. 2004;24:55-62.

23. Viebahn R. The use of ozone in Medicine. 3rd English ed. Iffezheim, Germany: ODREIPublishers; 1999.

24. Alonso I, et al. Formulario Nacional de Medicamentos. Segunda edicion. La Habana: Ed. Ciencias Medicas; 2011.

25. Hoffman R, Benz EJ, Shattil SS, et al. Hematology: Basic Principles and Practice. 4th ed. Orlando, Fl: Churchill Livingstone; 2005.
26. Ronald JH, Giclas PC. Diagnostic Immunology Laboratory Manual. New York, USA: Raven Press; 1991.

27. Suardíaz J, Cruz C, Colina A. Laboratorio Clinico. 1 ed. La Habana: Editorial Ciencias Medicas; 2004.

28. Weber-Mezell D, Kotanko P, Hauer AC, et al. Gender, age and seasonal effect on $\operatorname{IgA}$ deficiency: A study of 7293 Caucasians. Eur J Clin Invest. 2004;34(3):224-229.

29. Mendez IJ, Bellanti JA, Ovilla MR. Inmunodeficiencias primarias y alergia. Alerg Asma Inmunol Pediatr. 2008;17(1):14-34.

30. Urm SH, Yun HD, Fenta YA, Yoo KH, Abraham RS, Hagan J. Asthma and risk of selective $\operatorname{IgA}$ deficiency or common variable immunodeficiency: a population-based casecontrol study. Mayo Clin Proc. 2013;88(8): 813-21.

31. Notarangelo L, Casanova JL, Fisher A, Puck J, Rosen F, Seger R, Geha G. Primary immunodeficiency diseases: $\mathrm{Na}$ update. J Allergy Clin Immun. 2004;114:677-687.

32. Barrios M. Clinical evolution of the patient default of IgA treated with Transference factor. Hemat Imm Transf Med. 2004;20(3):180-184.

33. Bocci V, Luzzi E, Corradeshi F, Paulesu L, DiStefano A. Studies on the biological effects of ozone. An attempt to define conditions for optimal induction of cytokines. Lymphokine and Cytokine Res. 1993;12:121-126.

34. Bocci V. Ozonization of blood for the therapy of viral diseases and immunodeficiencies. A hypothesis. Medical hypotesis. 1992;39:30-34.

35. Bocci V, Borrelli E, Zanardi I, Travagli V. Oxygen-ozone therapy is at a cross-road. Revista Española de Ozonoterapia. 2011;1(1): 74-86.

36. Paulesu L, Luzzi E, Bocci V. Studies on the biological effects of ozone: 2. Induction of tumor necrosis factor (TNF $\alpha$ ) on human leucocytes. Lymphokines Cytokines Res. 1991;10:409-412.

37. Curse JM, Lewis RE. Atlas of Immunology. Second Edition. Florida: CRC Press; 2004.

38. Rhee SG, Bae YS, Lee SR, Kwon J. Hydrogen peroxide. A key messenger that modulates protein phosphorylation though cysteine oxidation. Sci STKE. 2000;2000(53):1. PubMed PMID: 11752613. doi: 10.1126/stke. 2000.53.pe1. 
39. Stites DP, Terr AI, Parslow TG. Inmunologia basica y clinica. Novena Edicion. Mexico: El Manual Moderno, S.A de C.V; 1998.

40. Lekstrom-Himes JA, Gallin JI. Immunodeficiency diseases caused by defects in phagocytes. N Engl J Med. 2000;343:1703-1713.

41. Aderem A. Underbil DM. Mechanism of phagocytes in Macrophages. Ann Rev Immunol. 2009;170:553-623.
42. Guanche D, Zamora Z, Hernandez F, et al. Effect of ozone/oxygen mixture on systemic oxidative stress and organic damage. Toxicol Mech Methods. 2010;20(1):25-30.

43. Aubourg P. L'ozone medical: Production, posologie, modes d'applications cliniques. Bull Med Soc Med Paris. 1938;52:745-749.

44. Bocci V. Is it true that ozone is always toxic? The end of a dogma. Toxicol Appl Pharm. 2006;216:493-504. 